\title{
PENGARUH MODEL PEMBELAJARAN KOOPERATIF TIPE GROUP INVESTIGATION (GI) TERHADAP KEMAMPUAN PEMECAHAN MASALAH MATEMATIS SISWA DI KELAS VIII SMP \\ NEGERI 2 STABAT TAHUN AJARAN 2018/2019 \\ Imelda Wardani Br Rambe, Shella Oktapiani STKIP Budidaya Binjai
}

\begin{abstract}
ABSTRAK
Penelitian ini bertujuan untuk mengetahui terdapat pengaruh model pembelajaran kooperatif tipe Group Investigation (GI) terhadap kemampuan pemecahan masalah matematis siswa pada materi ajar SPLDV dikelas VIII SMP Negeri 2 Stabat. Sampel penelitian di ambil sebanyak 28 siswa yang berada di kelas VIII-2. Instrument penelitian ini adalah tes kemampuan pemecahan masalah berbentuk essay. Sebelum tes diujicobakan, terlebih dahulu diuji validitas dan reliabilitas tes tersebut. Hasil uji validitas diperoleh bahwa soal pretest dan soal posttest valid. Uji reliabilitas soal pretest posttest reliabel. Pada penelitian ini, desain yang digunakan adalah One Group Pre-Test Post-Test. Sebelum pengujian hipotesis terlebih dahulu dilaukan uji persyaratan analisis data yakni uji normalitas dan uji homogenitas. Normalitas diuji dengan menggunakan titik lilifors dan homogenitas dengan menggunakan uji F. Dari pengujian yang dilakukan diperoleh bahwa kedua sampel berdistribusi normal dan homogen. Pengujian hipotesis dilakukan dengan uji-t dimana pengumpulan data untuk variabel kemampuan pemecahan masalah matematis diperoleh $H_{0}$ ditolak, dan $H_{a}$ diterima. Dari pengujian hipotesis diatas dapat disimpulkan bahwa terdapat pengaruh yang signifikan pada model pembelajaran kooperatif tipe Group Investigation (GI) terhadap kemampuan pemecahan masalah matematis siswa pada materi ajar SPLDV di kelas VIII SMP Negeri 2 Stabat tahun ajaran 2018/2019.
\end{abstract}

Kata Kunci :Group Investigation, Kemampuan Pemecahan Masalah

\section{PENDAHULUAN}

Salah satu tujuan pendidikan matematika dalam Permendiknas No.22 Tahun 2006 dalam Ichwanu (2014) adalah peserta didik memiliki kemampuan memecahkan masalah yang meliputi kemampuan memahami masalah, merancang model matematika, menyelesaikan model dan menafsirkan solusi yang diperoleh. Terkait dengan salah satu tujuan tersebut, pemecahan masalah memegang peranan yang sangat penting dalam pembelajaran matematika. Pemecahan masalah matematis merupakan salah satu kegiatan matematika yang dianggap penting mulai dari sekolah dasar sampai sekolah menengah, namun pemecahan masalah masih dianggap bagian yang paling sulit dalam matematika.

Pentingnya kemampuan pemecahan masalah matematis dimiliki siswa ditegaskan oleh Branca dalam Erik Santoso (2016:10) yaitu : (1) Kemampuan 
pemecahan masalah merupakan tujuan umum pengajaran matematika; (2) Pemecahan masalah yang meliputi metode, prosedur dan strategi merupakan proses inti dan utama dalam kurikulum matematika; (3) Pemecahan masalah merupakan kemampuan dasar dalam belajar matematika. Suatu soal atau pertanyaan dikatakan suatu masalah jika dalam penyelesainnya memerlukan suatu kreativitas, pengertian dan pemikiran imajinasi dari setiap orang yang menghadapi masalah tersebut.Masalah matematika tersebut biasanya berbentuk soal cerita, membuktikan, menciptakan atau mencari suatu pola matematika.

Faktanya berdasarkan hasil observasi langsung di sekolah, sebagian besar kegiatan pembelajaran masih berpusat pada guru dengan menerapkan metode pembelajaran konvensional. Dengan pembelajaran ini partisipasi dan keaktifan siswa dalam mengikuti kegiatan belajar belum optimal. Proses pembelajaran yang seperti ini yang menyebabkan kemampuan pemecahan masalah matematis siswa masih sangat rendah.

Hal yang sama terjadi di SMP Negeri 2 Stabat, yang menunjukan bahwa kemampuan pemecahan masalah matematis siswa masih rendah. Hal tersebut dapat dilihat dari kemampuan siswa menyelesaikan tes diagnosa yang diberikan peneliti.

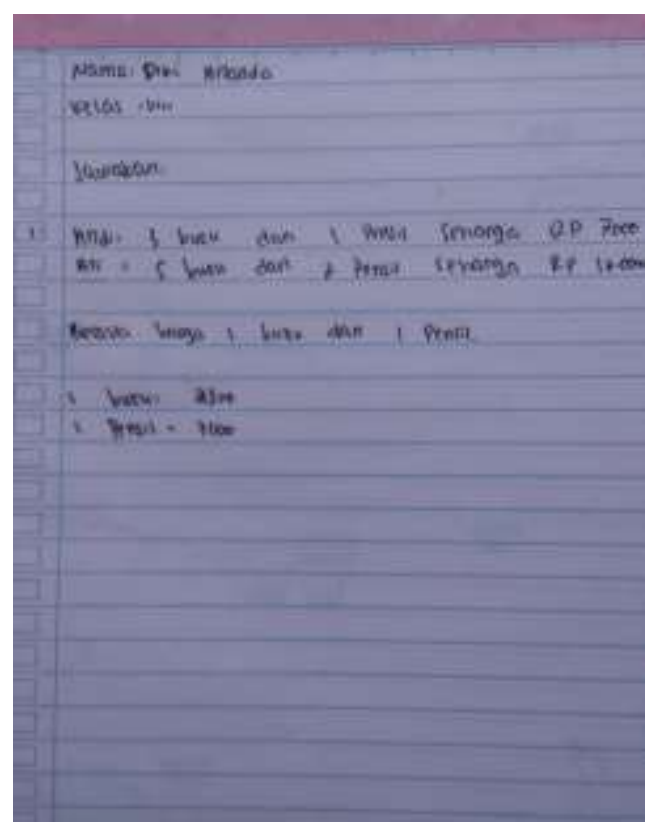

Gambar 1. Penyelesaian Masalah 
Berdasarkan hasil tes diagnostik diatas, dapat dilihat bahwa kemampuan pemecahan masalah matematis siswa masih sangat rendah, karena siswa hanya dapat mengetahui informasi yang terdapat dari soal cerita namun siswa tidak dapat menentukan rancangan penyelesaian soal selanjutnya karena siswa tidak bisa mengubah informasi dalam soal cerita menjadi bentuk matematikanya.

Untuk mengatasi masalah ini dibutuhkan sebuah model yang tepat sehingga dalalm proses pembelajaran siswa lebih berperan dan belajar aktif. Salah satu cara untuk meningkatkan kualitas pembelajaran adalah guru mengajar dengan menentukan dan menggunakan strategi pembelajaran yang tepat. Salah satu model yang diperkirakan dapat digunakan adalah pembelajaran kooperatif (Cooperative Learning). Kumalasari dalam Rino Richardo (2015) Cooperative Learning merupakan model pembelajaran melalui kelompok kecil yang saling bekerjasama dalam memaksimalkan kondisi belajar untuk mencapai tujuan belajar. Model pembelajaran kooperatif masih jarang digunakan padahal berdasarkan hasil-hasil penelitian yang ditelaah oleh Slavin dalam Trianto (2009) yang menunjukan bahwa teknik-teknik pembelajaran kooperatif lebih unggul dalam meningkatkan hasil belajar dibandingkan pengalaman individual atau kompetitif.

Ada beberapa teknik model pembelajaran kooperatif yang dapat dikembangkan dalam pembelajaran matematika, salah satu teknik tipe GI (Group Investigation). Model pembelajaran kooperatif tipe GI (Group Investigation) pertama kali dikembangkan oleh Herbert Thelen dan di perluas oleh Sharan Sharen dalam Hija (2016) dimana pada model pembelajaran kooperatif tipe GI (Group Investigation) siswa dapat belajar dan bekerja sama dalam kelompok kecil yang bersifat collaborative. GI (Group Investigation) dalam solihatin (2005) adalah cara yang efektif untuk mengubah pola diskusi didalam kelas, model pembelajaran ini memiliki prosedur yang ditetapkan untuk membantu siswa belajar berkomunikasi, menghargai pendapat siswa lain, siswa terlatih untuk mempertanggung jawabkan jawaban yang diberikan, mengembangkan dan melatih keterampilan, dan selalu berfikir tentang cara atau strategi yang digunakan sehingga didapat suatu kesimpulan yang berlaku umum dan saling membantu satu sama lain. Adapun sintak model pembelajaran group investigation (GI) adalah sebagai berikut ; (1) Tahap Seleksi, Para siswa memilih berbagai subtopik dari suatu bidang masalah umum yang biasanya digambarkan terlebih dahulu oleh guru, namun dalam 
penelitian ini guru membantu siswa dalam menentukan subtopik pokok bahasan. Selanjutnya siswa diorganisasikan ke dalam kelompok-kelompok yang berorientasi pada tugas yang beranggotakan 2-6 orang dengan komposisi kelompok heterogen. (2) Tahap Perencanaan Kerja Sama, para siswa dan guru merencanakan prosedur belajar khusus, tugas, dan tujuan umum yang konsisten dengan berbagai topik dan subtopik yang telah dipilih. (3) Tahap Implementasi, para siswa melaksanakan rencana yan telah dirumuskan pada langkah sebelumnya. Pembelajaran harus melibatkan berbagai aktivitas dan keterampilan dengan variasi yang luas. Pada tahap ini guru harus mendorong para siswa untuk melakukan penelitian dengan memanfaatkan berbagai sumber. Guru secara terus menerus mengikuti kemajuan tiap kelompok dan memberikan bantuan jika diperlukan. (5) Tahap Analisis dan Sintesis, para siswa menganalisis dan membuat sintesis atas berbagai informasi yang diperoleh pada langkah sebelumnya, lalu berusaha meringkasnya menjadi suatu penyajian yang menarik di depan kelas. (6) Tahap Penyajian Hasil Akhir, semua kelompok menyajikan presentasinya atas topik-topik yang telah dipelajari agar semua siswa di dalam kelas saling terlibat dan mencapai suatu perspektif yang luas mengenai topik tertentu. (7) Tahap Evaluasi, para siswa dan guru melakukan evaluasi mengenai kontribusi tiap kelompok terhadap pekerjaan kelas sebagai suatu keseluruhan.Evaluasi dapat dilakukan pada setiap siswa secara individual maupun kelompok, atau keduanya.

Kemampuan pemecahan masalah matematis adalah suatu tindakan untuk menyelesaikan masalah atau proses yang mengunakan kekuatan dan manfaat matematika dalam menyelesaikan masalah, yang juga merupakan metode penemuan solusi melalui langkah-langkah pemecahan masalah. Adapun langkah-langkahnya: 1) Memahami masalah; 2) Merencanakan penyelesaian masalah; 3) Menyelesaikan masalah sesuai rencana; 4) Memeriksa kembali prosedur dan hasil penyelesaian. Maka dari itu, peneliti menerapkan model pembelajaran kooperatif tipe GI terhadap kemampuan pemecahan masalah matematis siswa di kelas VIII SMP Negeri 2 Stabat tahun ajaran 2018/2019. Pada penelitian ini, peneliti mengambil materi SPLDV di kelas VIII. 


\section{METODE}

Jenis penelitian ini adalah Pra-Experiment Desain. Menurut Emzir dalam Jakni (2006) penelitian pra-experiment desain (non-design) merupakan dasar dari penelitian eksperimen. Dalam penelitian ini akan dicari pengaruh anatara dua variabel. Variabel pertama adalah model pembelajaran Group Investigation (GI) dan variabel kedua adalah kemampuan pemecahan masalah matematis.

Pola desain penelitian yang digunakan adalah One Group Pre-Test Post-Test. Desain yang merupakan ekperimen yang dilaksanakan pada satu kelompok saja tanpa kelompok pembanding. Desain ini digambarkan sebagai berikut :

Tabel 1. Desain Penelitian

\begin{tabular}{|c|c|c|c|}
\hline Kelompok & $\begin{array}{c}\text { Pengukuran I } \\
(\text { Pre-Test })\end{array}$ & Perlakuan & $\begin{array}{c}\text { Pengukuran II } \\
(\text { Post-Test })\end{array}$ \\
\hline Eksperimen & $\boldsymbol{O}_{1}$ & $\mathrm{X}$ & $\boldsymbol{O}_{2}$ \\
\hline
\end{tabular}

Populasi penelitian ini adalah seluruh siswa yang duduk dikelas VIII SMP Negeri 2 Stabat Tahun Pelajaran 2018/2019 sebanyak 154 siswa yang terdiri dari enam kelas. Sampel dalam penelitian ini dipilih secara probability sampling dengan teknik cluster random sampling. Sugiyono menjelaskan cluster random sampling adalah teknik mengambil sampel bukan didasarkan individu, melainkan didasarkan kelompok atau subjek yang secara alami berkumpul bersama.Peneliti mengambil kelas VIII $_{2}$ sebagai kelas eksperimen dengan diberikan perlakuan model pembelajaran Group Investigation. Pertimbangan peneliti mengambil kelas tersebut karena peneliti telah melakukan studi pendahuluan pada kelas tersebut sehingga diharapkan hasilnya sesuai tujuan penelitian ini.

Dalam penelitian ini ada dua variabel yang akan diteliti,variabel bebasdalam penelitian ini adalah model pembelajaran Group Investigation (GI). Variabel terikat dalam penelitian ini adalah kemampuan pemecahan masalah matematis siswa pada pokok bahasan SPLDV. Selain itu, peneliti juga melakukan uji coba tes tersebut untuk melihat validitas tes dan realibilitas tes, tingkat kesukaran soal, dan daya beda soal. Berikut hasil dari uji coba tes yang dilakukan peneliti : 
Tabel 2 . Hasil Perhitungan Validitas Soal Pre-test dan Post-test

\begin{tabular}{|c|c|c|c|c|c|c|}
\hline \multirow{2}{*}{ No } & \multicolumn{3}{|c|}{ Pre-test } & \multicolumn{3}{c|}{ Post-test } \\
\cline { 2 - 7 } & $\boldsymbol{r}_{\text {hitung }}$ & $\boldsymbol{r}_{\text {tabel }}$ & Keterangan & $\boldsymbol{r}_{\text {hitung }}$ & $\boldsymbol{r}_{\text {tabel }}$ & Keterangan \\
\hline $\mathbf{1}$ & 0,410 & 0,374 & Valid & 0,763 & 0,374 & Valid \\
\hline $\mathbf{2}$ & 0,668 & 0,374 & Valid & 0,812 & 0,374 & Valid \\
\hline $\mathbf{3}$ & 0,639 & 0,374 & Valid & 0,645 & 0,374 & Valid \\
\hline $\mathbf{4}$ & 0,653 & 0,374 & Valid & 0,747 & 0,374 & Valid \\
\hline $\mathbf{5}$ & 0,622 & 0,374 & Valid & 0,638 & 0,374 & Valid \\
\hline
\end{tabular}

Tabel 3. Hasil Perhitungan Reliabilitas Soal Pre-test dan Post-test

\begin{tabular}{|c|c|c|c|}
\hline Soal & $\boldsymbol{r}_{\text {hitung }}$ & $\boldsymbol{r}_{\text {tabel }}$ & Keterangan \\
\hline Pre-test & 0,563 & 0,374 & Reliabel \\
\hline Post-test & 0,771 & 0,374 & Reliabel \\
\hline
\end{tabular}

Tabel 4. Hasil Perhitungan Indeks Kesukaran Soal Pre-test dan Post-test

\begin{tabular}{|c|c|c|c|c|c|c|c|c|}
\hline \multirow{2}{*}{ No. } & \multicolumn{4}{|c|}{ Pre - test } & \multicolumn{4}{c|}{ Post - test } \\
\cline { 2 - 9 } & B & JS & P & Kategori & B & JS & P & Kategori \\
\hline $\mathbf{1}$ & 150 & 280 & 0,54 & Sedang & 159 & 280 & 0,57 & Sedang \\
\hline $\mathbf{2}$ & 110 & 280 & 0,39 & Sedang & 151 & 280 & 0,54 & Sedang \\
\hline $\mathbf{3}$ & 143 & 280 & 0,51 & Sedang & 157 & 280 & 0,56 & Sedang \\
\hline $\mathbf{4}$ & 133 & 280 & 0,48 & Sedang & 132 & 280 & 0,47 & Sedang \\
\hline $\mathbf{5}$ & 99 & 280 & 0,35 & Sedang & 124 & 280 & 0,44 & Sedang \\
\hline
\end{tabular}

Tabel 5. Hasil Perhitungan Daya Beda Soal Pre-test dan Post-test

\begin{tabular}{|c|c|c|c|c|}
\hline \multirow{2}{*}{ No } & \multicolumn{2}{|c|}{ Pre-test } & \multicolumn{2}{c|}{ Post-test } \\
\cline { 2 - 5 } & Daya Beda Soal & Kategori & Daya Beda Soal & Kategori \\
\hline $\mathbf{1}$ & 0,086 & Buruk & 0,179 & Buruk \\
\hline $\mathbf{2}$ & 0,229 & Cukup & 0,250 & Cukup \\
\hline $\mathbf{3}$ & 0,221 & Cukup & 0,221 & Cukup \\
\hline $\mathbf{4}$ & 0,250 & Cukup & 0,229 & Cukup \\
\hline $\mathbf{5}$ & 0,321 & Cukup & 0,229 & Cukup \\
\hline
\end{tabular}

\section{HASIL DAN PEMBAHASAN}

Hasil perhitungan pretes dan postes diatas dapat dilihat perbedaan rata-rata pretes dan postes pada kelas eksperimen. Secara ringkas nilai rata-rata siswa kedua kelas baik pretes maupun postes dapat dilihat pada tabel berikut : 
Tabel 6. Ringkasan Rata-rata Nilai Pretes dan Postes

\begin{tabular}{|c|c|c|}
\hline Keterangan & \multicolumn{2}{|l|}{ Kelas Eksperimen } \\
\cline { 2 - 3 } & Pretes & Postes \\
\hline Jumlah nilai & 805 & 1940 \\
\hline Rata-rata & 28,75 & 69,28 \\
\hline
\end{tabular}

Pengujian normalitas data dilakukan dengan uji lilliefors dengan ketentuan jika $L_{o}<L_{\text {tabel }}$ maka disimpulkan bahwa sebaran data berdistribusi normal dan demikian sebaliknya. Uji normalitas data pretes kelas eksperimen diperoleh $L_{o}(0,1189)<$ $L_{\text {tabel }}(0,166)$. Data postes kelas eksperimen diperoleh $L_{o}(0,1509)<L_{\text {tabel }}(0,166)$.

Tabel 7. Ringkasan Hasil Uji Normalitas Data dengan Liliefors

\begin{tabular}{|l|c|c|l|}
\hline \multirow{2}{*}{ Data } & \multicolumn{2}{|c|}{ Kelas Eksperimen } \\
\cline { 2 - 4 } & $\boldsymbol{L}_{\text {hitung }}$ & $\boldsymbol{L}_{\text {tabel }}$ & Ket. \\
\hline Pre tes & 0,1189 & 0,166 & Normal \\
\hline Post test & 0,1509 & 0,166 & Normal \\
\hline
\end{tabular}

Untuk menguji homogenitas dari data yang diperoleh selama penelitian, digunakan uji statistic-F.untuk kriteria pengujian data sampel adalah homogeny jika $F_{\text {hitung }}<F_{\text {tabel }}$ pada taraf nyata $\alpha=0,05$. Uji homogenitas pretes pada kemampuan pemecahan masalah kelas eksperimen diperoleh $F_{\text {hitung }}(1,345)<F_{\text {tabel }}(1,88)$ dan data postes kemampuan pemecahan masalah kelas eksperimen diperoleh $F_{\text {hitung }}(1,345)<F_{\text {tabel }}(1,88)$.

Tabel 8. Data Hasil Uji Homogenitas

\begin{tabular}{|l|l|c|l|}
\hline Data & $\boldsymbol{F}_{\text {hitung }}$ & $\boldsymbol{F}_{\text {tabel }}$ & Keterangan \\
\hline Pretes & 1,345 & 1,88 & Homogen \\
\hline Posttes & 1,345 & 1,88 & Homogen \\
\hline
\end{tabular}

Pengujian hipotesis ini diujikan dengan menggunakan Uji-t dengan kriteria jika $t_{\text {hitung }}>t_{\text {tabel }}$ berarti $H_{0}$ ditolak dan $H_{a}$ diterima. Berdasarkan kriteria Uji-t, jika $t_{\text {hitung }}>t_{\text {tabel }}$ maka $H_{a}$ diterima. Dari hasil analisis diatas maka $H_{a}$ diterima yang menyatakan bahwa "terdapat pengaruh model pembelajaran kooperatif tipe GI terhadap kemampuan pemecahan masalah matematis siswa kelas VIII SMP Negeri 2 Stabat tahun ajaran 2018/2019". 


\section{SIMPULAN}

Berdasarkan hasil penelitian yang diperoleh dari analisis data diperoleh kesimpulan yaitu terdapat pengaruh signifikan model pembelajaran kooperatif tipe GI(Group Investigation) terhadap kemampuan pemecahan masalah matematis siswa pada meteri bilangan dikelas VIII SMP Negeri 2 Stabat tahun ajaran 2018/2019.

\section{REFERENSI}

Hija, Alvia, dkk. 2016. Pengaruh Model Pembelajaran Group Investigation (GI) Terhadap Kemampuan Pemecahan Masalah Matematis Siswa Pada Materi Peluang Kelas X MIPA.Vol 1 no.1.hlm 25-33.

Ichwanu. 2014. Pengembangan Perangkat Pembelajaran Matematika Menggunakan Lembar Kerja Sosial Alternatif Untuk Siswa SMP Kelas VII Dalam Pemecahan Masalah Tentang Segiempat dan Segitiga Jurnal Pendidikan Matematika. Volume 3 No 3.

Jakni. 2016. Metodologi Penelitian Eksperimen Bidang Pendidikan. Bandung : Alfabeta .

Richardo, Rino. Juni 2015.Eksperimentasi Model Pembelajaran Kooperatif Tipe Investigasi Kelompok (Group Investigation) Terhadap Hasil Belajar Matematika Berdasarkan Gaya Belajar Siswa. Jurnal Ilmiah Edu Research Vol.4 No.1.

Santoso, Erik. Edisi Juli 2016. Pengaruh Penggunaan Model Pembelajaran Kooperatif Tipe Group Investigation Terhadap Kemampuan Pemecahan Masalah Matematik Siswa di SMK Galuh Rahayu Ciamis.Vol. 1 No.1.hal.10-20.

Trianto.2009. Mendesain Model Pembelajaran Inovatif-Progresif.Jakarta : Kencana.

Trianto. 2011. Model-Model Pembelajaran Inovatif Berorientasi Konstruktivistik, Jakarta : Prestasi Pustaka 